\title{
A 6-month comparison of quality of life and mood states between physically active and sedentary college students
}

\author{
Uma comparação durante seis meses da qualidade de vida e estados de \\ humor entre universitários fisicamente ativos e sedentários
}

Franco Noce $^{1}$, Henrique de Oliveira Castro², Tadeu Sartini Ferreira ${ }^{3}$, James Guo ${ }^{4}$, André Gustavo Pereira de Andrade ${ }^{5}$, Varley Teoldo da Costa ${ }^{1}$

\begin{abstract}
Physical inactivity has been described as one of the major public health problems of the 21st century. Physical activity plays an important role in reducing the prevalence of sedentarism, improving the quality of life and improving individuals' mental health.

Objective: This study aimed to perform a 6-month comparison of quality of life (QOL) and mood states (MS) between physically active and sedentary college students.

Methods: A sample of 32 individuals completed questionnaires to assess their level of physical activity, quality of life and mood states. They were separated into two groups: sedentary $(n=15)$ and physically active $(n=17)$. The International Physical Activity Questionnaire (IPAQ) was used for assessing PA levels, the WHO Quality of Life-BREF for QOL and the Brazilian Mood Scale for MS. We used factorial analysis of variance with repeated measures and post-hoc Tukey test $(p \leq 0.05)$ for QOL and MS inferential analysis.
\end{abstract}

Results: QOL was significantly higher for the physically active group in Environment and Social Relationships domains. Similarly, MS showed increased scores in Vigor dimension for the physically active group after six months.

Conclusions: These results suggest PA can positively influence aspects of an individuals' quality of life. However, our data did not show a significant influence of PA on mood states.

Keywords: Quality of Life. Mood Disorders. Physical activity. Sedentary Lifestyle.

\section{RESUMO}

A inatividade física tem sido descrita como um dos principais problemas de saúde pública do século XXI. Neste contexto, a atividade física desempenha um papel importante na redução da prevalência de sedentarismo, melhorando a qualidade de vida e a saúde mental dos indivíduos.

Objetivo: Este estudo teve como objetivo analisar a influência de seis meses de atividade física (AF) na qualidade de vida (QV) e estados de humor (EH) de adultos jovens.

1. Professor Doutor da Universidade Federal de Minas Gerais UFMG. Laboratório de Psicologia do Esporte - LAPES/UFMG.

2. Professor Mestre do Centro Universitário Estácio Brasília. Doutorando em Ciências do Esporte - UFMG

3. Graduado em Medicina pelo Centro Universitário de Belo Horizonte - Uni-BH. Residente em Cirurgia Geral no Hospital Alberto Cavalcanti - FHEMIG.

4. Bacharel em Ciências Bológicas pela Cornell University.

5. Professor Doutor da UFMG. Laboratório de Biomecânica BIOLAB/UFMG
Correspondencia Franco Noce Universidade Federal de Minas Gerais (UFMG). Av. Presidente Antônio Carlos, 6.627 - Pampulha. 31310-250. Belo Horizonte, MG, Brasil.

Recebido em 24/11/2014 Aprovado em 09/06/2015 
Métodos: Uma amostra de 32 indivíduos completou uma bateria de questionários para avaliar o seu nível de atividade física, qualidade de vida e estados de humor. Eles foram separados em dois grupos: sedentários $(n=15)$ e fisicamente ativos ( $n=17)$. O International Physical Activity Questionnaire (IPAQ) foi utilizado para avaliar os níveis de AF, o WHO Quality of Life-BREF (WHOQOL_Bref) para QV e a Escala Brasileira de Humor (BRAMS) para os EH. Foi realizada análise fatorial de variância com medidas repetidas e teste post-hoc de Tukey $(\mathrm{p} \leq 0,05)$ para QV e análise inferencial para os $\mathrm{EH}$.

Resultados: Escores de QV foram significantemente maiores para o grupo fisicamente ativo nos domínios ambiental e social. Da mesma forma, EH apresentaram maiores escores na dimensão Vigor para o grupo fisicamente ativo depois de seis meses, sem contudo, atingir os níveis de significância estatística. Conclusões: Estes resultados sugerem que AF pode influenciar positivamente aspectos na qualidade de vida do indivíduo. Contudo, os dados não evidenciam uma influência significativa da AF nos estados de humor.

Palavras-chave: Qualidade de Vida. Transtornos do Humor. Atividade física. Sedentarismo.

\section{Introduction}

Physical inactivity has been described as one of the major public health problems of the 21 st century. ${ }^{1}$ Reliance on technology can diminish the body's energy consumption during daily activities, increasing the incidence of sedentarism. ${ }^{2}$ In this context, being physically active plays an important role in ${ }^{3}$ improving quality of life ${ }^{4}$ and mental health. ${ }^{5}$

Physical activity is defined as any body movement that spends energy above resting levels. ${ }^{6} \mathrm{Ac}-$ cording to a large number of publications, being regularly active improves the quality and length of life. ${ }^{7-10}$ Regular physical activity can lower the risk of mortality, cardiopathies ${ }^{8}$, strokes, hypertension, type II diabetes, osteoporosis, obesity, colon cancer and breast cancer. ${ }^{2,11}$ Exercise also reduces anxiety, depression ${ }^{12}$, cognitive decline ${ }^{13}$ and stress levels, and improves overall well-being and mental energy. ${ }^{14,15,16}$ Physical activity programs have been suggested as a necessary course of action to promote healthy lifestyles and a better quality of life. ${ }^{17,18,19}$

Although "quality of life" is frequently used in medical literature, a consensus about its meaning is not yet realized. ${ }^{20,21}$ It has been described as the self-perception of one's position in life which considers personal goals, expectations, standards and concerns. This definition incorporates aspects related to physical health, psychological state, level of independence, sociocultural and environmental relationships, and personal beliefs. ${ }^{22,23}$ In various populations, higher number of friends, financial sta- tus and education are associated with increased life satisfaction. ${ }^{24}$

Psychological factors are also of great importance for the perception of quality of life. According to McNair et al.(1992) and Lane (2007), understanding a person's psychological aspects requires not only the inclusion of physiological and behavioral data but also special attention to mood states and mood swings. Regular physical activity is described as a positive contributor to the improvement of quality of life, energy level and mood states. ${ }^{8,26}$

Brazilian Mood Scale (BRAMS) was considered an appropriate sports psychology instrument for assessing mood profiles through a short questionnaire. ${ }^{27}$ Sports psychology instruments are useful for early identification of problems both in the team and team's staff mood states. ${ }^{28}$ Moreover, it monitors emotional responses to injury, performance prediction, and overtraining rehabilitation. ${ }^{28-33}$ Psychometric instruments may have their application extended to a non-athlete population, from teenagers to adults, either for mood states or training workload assessment. ${ }^{34-36}$

In this context, this study aimed to perform a 6-month comparison of quality of life and mood states between physically active and sedentary individuals.

\section{Material and methods}

College students over 18 years old in good health were included. Individuals who were previously diagnosed with chronic diseases, did not com- 
plete the questionnaires for six months, or changed their physical activity status during the study were excluded.

Our sample recruitment method consisted of printed advertisement and oral presentations in class at the Universities, which were chosen by convenience, in a total of four private Universities. Those who were interested in participating contacted the research team by phone, email or in person. After a detailed explanation about the study, volunteers had the informed consent signed. They were free to leave the study at any point.

We used the short version of the International Physical Activity Questionnaire (IPAQ), an instrument validated for the Portuguese language by Matsudo et al (2001) for Brazilian subjects ${ }^{37}$ in order to determine individuals physical activity levels. IPAQ classifies an individual as active if he or she engages in physical activity on a moderate or high intensity. An individual is considered sedentary if he or she is inactive or does not achieve moderate or intense levels of physical activity. ${ }^{38}$ IPAQ has been used in several studies related to health and illness. ${ }^{39-42}$ IPAQ is divided into five domains of physical activity, as follows: exercise during work time, exercise during domestic activities, exercise during sports, and sitting down. The level of physical activity is determined by the sum of the minutes spent in all the five domains, taking in consideration its intensity.

The WHOQOL_Bref questionnaire ${ }^{22}$ was administered to assess quality of life levels. The Brazilian validation of WHOQOL-BREF was accomplished in 2000 by Fleck et al. It is comprised of 26 questions, subjectively evaluating general quality of life (2 items) and 4 specific domains: physical health (7 items), psychological health (6 items), social relationships (3 items) and environment ( 8 items). Every question had a scale from 1 (very bad) to 5 (very good). All items were scored from 1 to 5 , and 3 items (pain and discomfort, medication, negative feelings) were reversely coded. Averages of each domain were calculated and transformed into percentiles. The WHOQOL_Bref questionnaire has been used in both healthy ${ }^{43,44,45}$ and sick individuals. ${ }^{46,47}$

The mood of the subject was determined by the Brunel Mood Scale in a version translated and validated for the Portuguese language - BRAMS. ${ }^{48}$
It consists of 24 items to assess mood change in the six dimensions - tension, depression, anger, vigor, fatigue, and confusion. Data are assessed and interpreted in percentile scores.

We used IPAQ in order to establish both the active and sedentary groups. Volunteers filled out the WHOQOL_Bref (in the morning) and BRAMS (once in the morning and another at the end of the day) questionnaires once a month for six months.

This study was approved by the University Center of Belo Horizonte Ethical Committee in Research (060/2006).

\section{Statistical Analysis}

The questionnaire data was analyzed using both descriptive and inferential statistical methods.

For "quality of life" we used factorial analysis of variance with repeated measures. The factors were "group" (experimental and control - 2 levels) and "time" (six months - 6 levels). Since BRAMS was administered twice a day, we added another factor to the "mood states" analysis: "time of the day" (beginning of day and end of day - 2 levels).

A post-hoc Tukey test was performed for both "quality of life" and "mood states". Significance was determined at $p \leq 0.05$, and the analysis was performed by the statistical package SPSS 18.0.

\section{Results}

Of 110 volunteers who presented to us, 82 met the criteria for inclusion. Fifty subjects were excluded because they either changed their physical activity status $(n=31)$ or did not complete the questionnaires for six months $(n=19)$. A total of 32 individuals completed the study, which included both men and women. They were categorized as sedentary $(n=15)$ or physically active $(n=17)$, and their ages ranged from 18 to 40 years (avg. 24.6 years). Physically active participants practiced dance, weight lifting or indoor cycling.

The data for active and sedentary groups throughout the 6 months will be presented in the charts below. The scores for General Quality of Life and specific domains (physical health, psychological health, social relationships and environment) are expressed as percentages. 


\section{Quality Of Life}

The active group exhibited higher scores than the sedentary group. There was no significant difference between the groups for general quality of life, physical health and psychological health, when compared per month or per 6 months.

The active group showed significantly higher "Environment" scores during the 6 months ( $p \leq$ 0.05). The active group also showed significantly higher "Social relationships" scores in both the 1st and the 6th months $(p \leq 0.05)$.

\section{Mood States}

Figures $2 a-2 f$ represent the analysis of each group's mood states (tension, depression, anger, vigor, fatigue, and confusion) at different times of the day (beginning or end).

Depression scores (Figure $2 \mathrm{~b}$ ) tended to be lower for the active group when compared to the

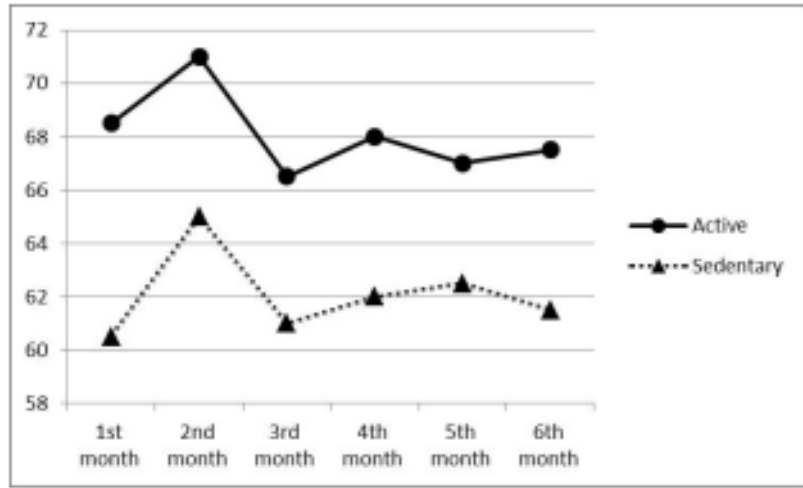

Figure1a: General quality of life scores for active and sedentary groups

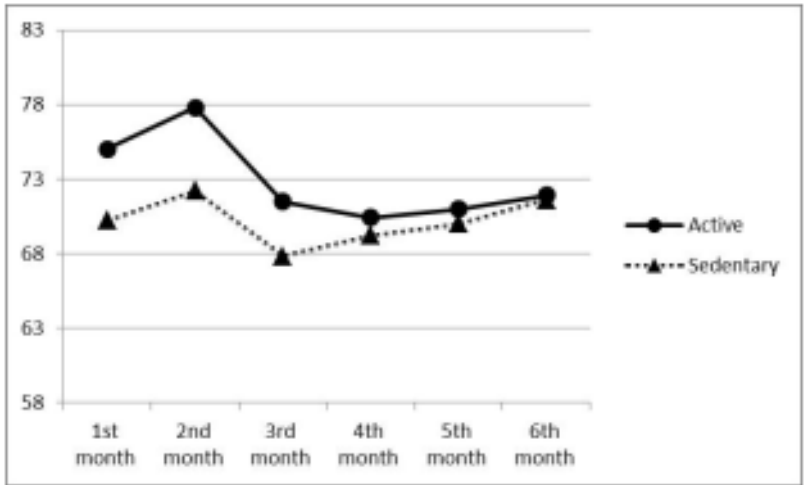

Figure1c: Psychological health scores for active and sedentary groups sedentary group. No significant difference was observed.

"Vigor" scores tended to decline at the end of the day in both groups (Figure 2d), although the active group exhibited higher scores in general. No significant difference was observed.

Fatigue scores increased at the end of the day for both groups (figure 2e), but the active group exhibited lower scores most of the time. No significant difference was observed.

\section{Discussion}

We found a positive relationship between physical activity and "social relationships" and "environment" scores for the active group. According to Soundy (2015), exercise can influence an individual's quality of life, providing an important sense of belonging and unity with others. Moreover, for those who enjoy sport, exercise provides a poten-

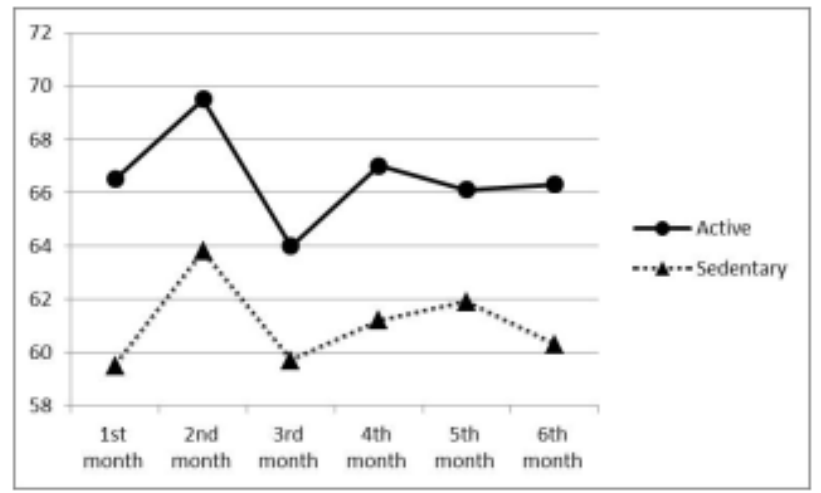

Figure1b: Physical health scores for active and sedentary groups

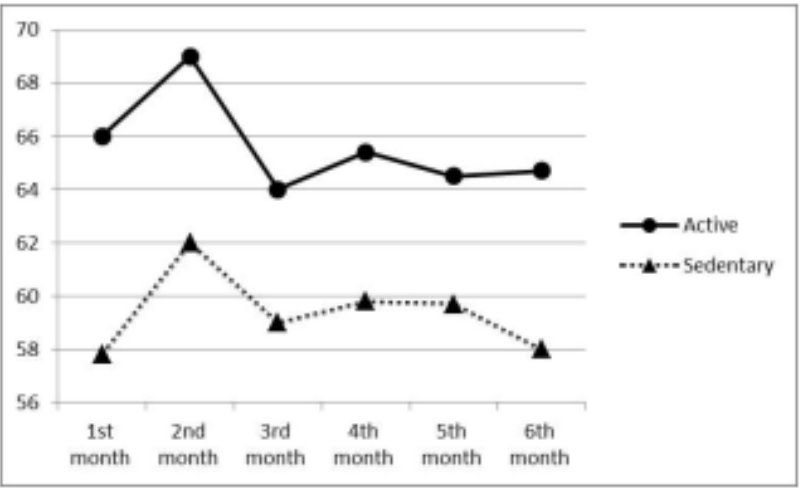

Figure1d: Environment scores for active and sedentary groups

http://www.revistas.usp.br/rmrp / http://revista.fmrp.usp.br 


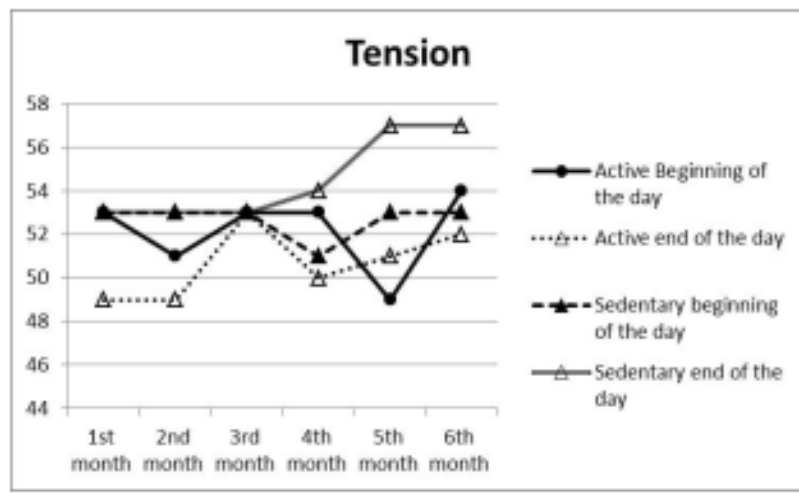

Figure 2a 'Tension' scores at the beginning and at the end of the day for active and sedentary groups

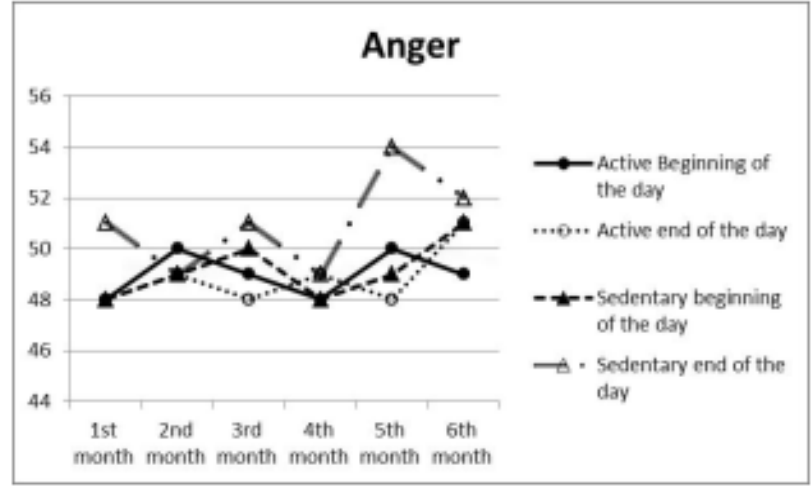

Figure 2c 'Anger' scores at the beginning and at the end of the day for active and sedentary groups

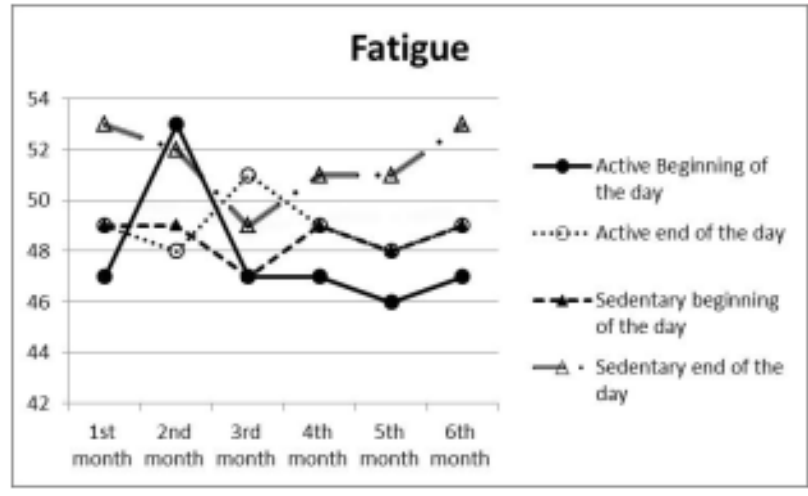

Figure $2 \mathrm{e}$ 'Fatigue' scores at the beginning and at the end of the day for active and sedentary groups

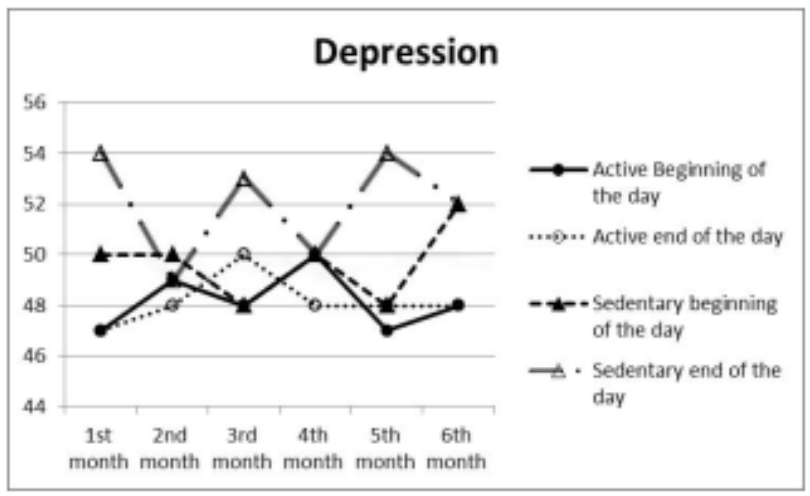

Figure $2 \mathrm{~b}$ 'Depression' scores at the beginning and at the end of the day for active and sedentary groups

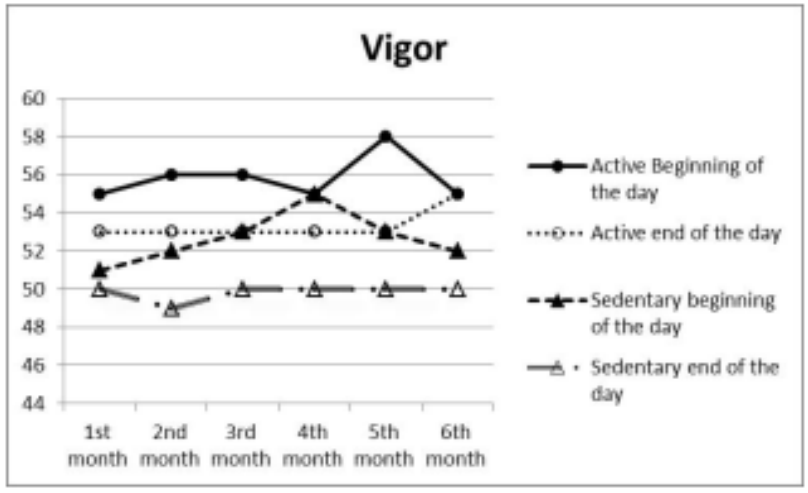

Figure $2 d$ 'Vigor' scores at the beginning and at the end of the day for active and sedentary groups

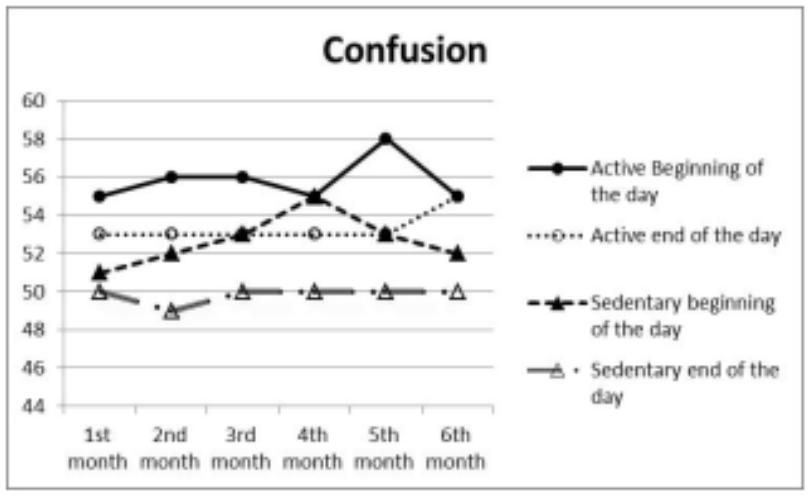

Figure 2f 'Confusion' scores at the beginning and at the end of the day for active and sedentary groups 
tial to develop a positive identity, which may be central to health psychology changes for individuals. 50

Søltoft, Hammer and Kragh (2009) investigated the relationship between quality of life and Body Mass Index (BMI) among English men and women. Results showed a significant association between lower BMI and quality of life after controlling for factors such age, gender and obesity related co-morbidities. These data demonstrate the potential for physical activity to lower body mass index and consequently improve the quality of life. ${ }^{49}$ Martin et al. (2009) aimed to demonstrate that physical exercise improves quality of life by testing 430 sedentary postmenopausal women for six months. Groups engaged in $50 \%$ or $100 \%$ or $150 \%$ of the recommended physical activity. Four physical aspects (physical functioning, limitations due to physical problems, pain and general health perception) and four mental aspects (limitations due to emotional problems, social functioning, vitality and mental health) were measured. Improvements in all aspects (physical and mental) were observed, with the exception of pain. Therefore, exercise improves quality of life in postmenopausal women, which agrees in concept with the present study.

According to the recommendation for adults from the American College of Sports Medicine and the American Heart Association, in order to promote health and stay healthy, adults should engage in aerobic physical activity of moderate intensity for a minimum period of 30 minutes, five days a week or of vigorous intensity for at least 20 minutes, three days a week. ${ }^{2}$ In the present study, the active group met the recommendation and was classified as active by the IPAQ. ${ }^{38}$ Combinations of activities of moderate to vigorous intensity can be performed to meet this recommendation. ${ }^{2}$

No significant differences were found in any of the mood states assessed. However, positive effects of physical activity are widely described in the literature. 49,51-59 Some research is done with non-athlete samples 60,61 , especially populations with some form of disability or disease; however, most of the publications refer specifically to athletes. $35,62,63,64$

Similarly to our study, Bittar et al. (2013) compared the effect of adapted sporting activities for six months in psychobiological aspects of elderly women using the Brunel Mood Scale. The Active group showed lower scores of anxiety and depression, better quality of life with increased functional capacity and vitality, and improved body image, when compared to the Control group.

Although significant differences were not observed in mood states, the majority of the scores were favorable in the active group, which suggests the beneficial effect of physical activity on mood states.

\section{Conclusions}

Research limitations such as sample loss and variables' control need to be pointed out. Considering our longitudinal research with a 6-month period of data collecting, only $28 \%$ of the volunteers completed the study. External factors that could possibly affect our results such as diet, lifestyle, social interaction and personal problems were not assessed. These limitations might explain why most of our results did not agree with the literature.

Our sample was comprised of healthy adults with a mean age of 25 years, a time in life when health has not yet been significantly affected by sedentarism. Thus, the perceived impact of physical activity on health, and consequently on quality of life, may be smaller. For young adults, a healthy lifestyle could, therefore, be dissociated from physical activity. The same is unlikely to be valid for older people, whose health is significantly influenced by their lifestyle and inherent degenerative factors associated with aging. Therefore, regular physical activity has a much greater potential to impact the quality of life of this population. This may be one reason some domains were unaffected by physical activity.

\section{References}

1. Dumith SC, Gigante DP, Domingues MR, Kohl HW, 3rd. Physical activity change during adolescence: a systematic review and a pooled analysis. Int J Epidemiol. . 2011;40:685-98.

2. Haskell WL, Lee IM, Pate RR, Powell KE, Blair SN, Franklin $\mathrm{BA}$, et al. Physical activity and public health: updated recommendation for adults from the American College of Sports Medicine and the American Heart Association. Med Sci Sports Exerc. 2007;39:1423-34. 
3. Crespo-Salgado JJ, Delgado-Martin JL, Blanco-Iglesias O Aldecoa-Landesa $\mathrm{S}$. [Basic guidelines for detecting sedentarism and recommendations for physical activity in primary care]. Atencion primaria / Sociedad Espanola de Medicina de Familia y Comunitaria. 2015;47:175-83.

4. Warburton DE, Nicol CW, Bredin SS. Health benefits of physical activity: the evidence. CMAJ. 2006;174:801-9.

5. Weinberg RS, Gould D. Foundations of Sport and Exercise Psychology, 6E: Human Kinetics; 2014.

6. Araújo DSMSd, Araújo CGSd. Aptidão física, saúde e qualidade de vida relacionada à saúde em adultos. Rev Bras Med Esporte. 2000;6:194-203.

7. King AC, Pruitt LA, Phillips W, Oka R, Rodenburg A, Haskell WL. Comparative effects of two physical activity programs on measured and perceived physical functioning and other health-related quality of life outcomes in older adults. J Gerontol. Series A: Biological sciences and medical sciences. 2000;55(2):M74-83.

8. Martin CK, Church TS, Thompson AM, Earnest CP, Blair SN Exercise dose and quality of life: a randomized controlled trial. Arch Intern Med.2009; 169:269-78.

9. Fleck M, Louzada S, Xavier M, Chachamovich E, Vieira G, Santos L, et al. Application of the Portuguese version of the abbreviated instrument of quality life WHOQOL-bref. Rev Saúde Pública. 2000;34:178-83.

10. Burns SH, Murray AD. Creating health through physical activity. Br J Sports Med. 2014;48:167-9.

11. Søltoft F, Hammer M, Kragh N. The association of body mass index and health-related quality of life in the general population: data from the 2003 Health Survey of England. Qual Life Res. 2009;18:1293-9.

12. Bernard P, Ninot G, Bernard P-L, Picot M-C, Jaussent A, Tallon $G$, et al. Effects of a six-month walking intervention on depression in inactive post-menopausal women: a randomized controlled trial. Aging Ment Health. 2014(ahead-of-print):1-8.

13. Lee Y, Kim J, Han ES, Chae S, Ryu M, Ahn KH, et al. Changes in physical activity and cognitive decline in older adults living in the community. AGE. 2015;37:1-10.

14. Steptoe A, Cox S. Acute effects of aerobic exercise on mood. Health Psychol. 1988;7:329.

15. Bahrke MS, Morgan WP. Anxiety reduction following exercise and meditation. Cognit Ther Res. 1978;2:323-33.

16. Berger BG, Owen DR. Mood Alteration with Swimming-Swimmers Really Do" Feel Better". Psychosom Med. 1983;45:42533.

17. Steptoe A, Cox S. Acute effects of aerobic exercise on mood. Health Psychol. 1988;7:329-40.

18. Coelho CM, Lessa TT, Carvalho RMd, Coelho LAMC, Scari RdS, Fernandes NdS, et al. Quality of life in female practitioners of Hatha Yoga. Motriz Rev Educ Fís. 2011;17:33-8.

19. Hawkes AL, Pakenham KI, Chambers SK, Patrao TA, Courneya KS. Effects of a multiple health behavior change intervention for colorectal cancer survivors on psychosocial outcomes and quality of life: a randomized controlled trial. Ann Behav Med. 2014;48:359-70.

20. Gill TM, Feinstein AR. A critical appraisal of the quality of quality-of-life measurements. Jama. 1994;272:619-26.

21. Netuveli G, Blane D. Quality of life in older ages. Br Med Bull. 2008;85:113-26.

22. Group W. Development of the World Health Organization WHOQOL-BREF quality of life assessment. Psychol Med.1998;28:551-8.
23. Biddle S, Fox KR, Boutcher SH. Physical activity and psychological well-being: Psychology Press; 2000.

24. Theuns P, Hofmans J, Mazaheri M, Van Acker F, Bernheim JL. Cross-national comparability of the WHOQOL-BREF: A measurement invariance approach. Qual Life Res. 2010;19:219-24.

25. McNair D, Lorr M, Droppleman L. Revised manual for the Profile of Mood States. San Diego, CA: Educational and Industrial Testing Services. 1992;731:732-3.

26. Hebestreit H, Schmid K, Kieser S, Junge S, Ballmann M, Roth $\mathrm{K}$, et al. Quality of life is associated with physical activity and fitness in cystic fibrosis. BMC Pulm Med. 2014;14:26.

27. Rohlfs ICPdM, Rotta TM, Luft CDB, Andrade A, Krebs RJ, Carvalho Td. A Escala de Humor de Brunel (Brums): instrumento para detecção precoce da síndrome do excesso de treinamento. Rev Bras Med Esporte. 2008;14:176-81.

28. Terry PC. Introduction to the special issue: perspectives on mood in sport and exercise. Journal of Applied Sport Psychology. 2000;12:1-4.

29. Weinberg RS, Gould D. Foundations of Sport and Exercise Psychology. 4th ed: Human Kinetics; 2006.

30. Lane AM. Mood and Human Performance: Conceptual, Measurement, and Applied Issues: Nova Science Publishers; 2007.

31. Crust L, Swann C, Allen-Collinson J, Breckon J, Weinberg R. A phenomenological exploration of exercise mental toughness: perceptions of exercise leaders and regular exercisers. Qualitative Research in Sport, Exercise \& Health. 2014; 6: 441-61.

32. Raglin JS. Psychological factors in sport performance: the Mental Health Model revisited. Sports Med.2001; 31:875-90.

33. Weinick RM, Jacobs EA, Stone LC, Ortega AN, Burstin H. Hispanic healthcare disparities: challenging the myth of a monolithic Hispanic population. Med Care. 2004;42:313-20.

34. Rohlfs I, Rotta T, Andrade A, Terry P, Krebs R, Carvalho T. The Brunel of mood scale (BRUMS): instrument for detection of modified mood states in adolescents and adults athletes and non athletes. Fiep Bulletin. 2005;75:281-4.

35. Terry PC, Lane AM, Fogarty GJ. Construct validity of the Profile of Mood States-Adolescents for use with adults. Psychol Sport Exerc. 2003;4:125-39.

36. Terry PC, Lane AM, Lane HJ, Keohane L. Development and validation of a mood measure for adolescents. J Sports Sci.1999;17:861-72.

37. Matsudo S, Araújo T, Marsudo V, Andrade D, Andrade E, Braggion G. Questinário internacional de atividade f1sica (IPAQ): estudo de validade e reprodutibilidade no Brasil. Rev Bras Ativ Fís Saúde. 2001;6:5-18.

38. Committee IR. Guidelines for data processing and analysis of the international physical activity questionnaire (IPAQ) - Short and long forms. Retrieved September. 2005;17:2008.

39. Cho SH, Choi M, Lee J, Cho H. [Relationship between Expectations Regarding Aging and Physical Activity among Middle Aged Adults in Urban Areas: Based on the Pender's Health Promotion Model]. Journal of Korean Academy of Nursing. 2015;45:14-24.

40. Dyrstad SM, Anderssen SA, Edvardsen E, Hansen BH. Cardiorespiratory fitness in groups with different physical activity levels. Scand J Med Sci Sports. 2016;26:291-8.

41. Vardar-Yagli N, Sener G, Saglam M, Calik-Kutukcu E, Arikan $\mathrm{H}$, Inal-Ince D, et al. Associations among physical activity, comorbidity, functional capacity, peripheral muscle strength and depression in breast cancer survivors. Asian Pac J Cancer Prev. 2015;16:585-9. 
42. Saglam M, Vardar-Yagli N, Savci S, Inal-Ince D, Calik-Kutukcu E, Arikan H, Coplu L. Functional capacity, physical activity, and quality of life in hypoxemic patients with chronic obstructive pulmonary disease. Int $\mathrm{J}$ Chron Obstruct Pulmon Dis. 2015; 10:423-8.

43. Krageloh CU, Henning MA, Billington R, Hawken SJ. The relationship between quality of life and spirituality, religiousness, and personal beliefs of medical students. Acad Psychiatry. 2015;39:85-9.

44. Chazan AC, Campos MR, Portugal FB. Quality of life of medical students at the State University of Rio de Janeiro (UERJ), measured using Whoqol-bref: a multivariate analysis. Ciênc Saúde Coletiva. 2015;20:547-56.

45. Farrokh-Eslamlou H, Oshnouei S, Heshmatian B, Akbari E. Premenstrual syndrome and quality of life in Iranian medical students. Sex Reprod Healthc. 2015;6:23-7.

46. Pangalila RF, van den Bos GA, Bartels B, Bergen M, Stam $\mathrm{HJ}$, Roebroeck ME. Prevalence of fatigue, pain, anxiety and depression in adults with Duchenne Muscular Dystrophy, and their associations with quality of life. Arch Phys Med Rehabil. 2015;96:1242-7.

47. Benetti-Pinto CL, Ferreira SR, Antunes A, Jr., Yela DA. The influence of body weight on sexual function and quality of life in women with polycystic ovary syndrome. Arch Gynecol Obstet. 2015;291:451-5.

48. Rohlfs I. Validação do teste de BRUMS para avaliação de humor em atletas e não atletas brasileiros. Master's thesis: Universidade do Estado de Santa Catarina, Florianópolis; 2006.

49. Soundy A, Roskell C, Stubbs B, Probst M, Vancampfort D. Investigating the benefits of sport participation for individuals with schizophrenia: a systematic review. Psychiatr Danub. 2015;27:2-13.

50. Soundy A, Kingstone T, Coffe P. Understanding the psychosocial process of physical activity for individuals with severe mental illness: A meta-ethnography. Mental Illness 2: L'Abate L; 2012.

51. Sun YL, Wang J, Yao JX, Ji CS, Dai Q, Jin YH. Physical exercise and mental health: cognition, anxiety, depression and self-concept. Sheng Li Ke Xue Jin Zhan. 2014;45:337-42.
52. Peluso MA, Guerra de Andrade LH. Physical activity and mental health: the association between exercise and mood. Clinics. 2005;60:61-70.

53. Penedo FJ, Dahn JR. Exercise and well-being: a review of mental and physical health benefits associated with physical activity. Curr Opin Psychiatr.2005;18:189-93.

54. Raglin JS. Exercise and mental health. Beneficial and detrimental effects. Sports Med.1990;9:323-9.

55. Ramsay R, Farmer R. Physical exercise and mental health. Br Med J.1988;296(6628):1069-70.

56. Szabadi E. Physical exercise and mental health. Br Med J.1988;296(6623):659-60.

57. Gleser J, Mendelberg H. Exercise and sport in mental health: a review of the literature. The Israel journal of psychiatry and related sciences. 1990;27:99-112.

58. Matta Mello Portugal E, Cevada T, Sobral Monteiro-Junior R, Teixeira Guimaraes T, da Cruz Rubini E, Lattari E, et al. Neuroscience of exercise: from neurobiology mechanisms to mental health. Neuropsychobiology. 2013;68:1-14.

59. Deslandes AC. Exercise and Mental Health: What did We Learn in the Last 20 Years? Front Psychiatry. 2014;5:66.

60. Bittar IGL, Guerra RLF, Lopes FC, Mello MTd, Antunes HKM. The effects of a program of teaching games in psychobiological aspects of elderly women. Rev Bras Geriatr Gerontol. 2013;16:713-25

61. Ribeiro BB, Pereira LS, Mello NF, Filippin NT. Relação da incapacidade funcional, fadiga e depressão com a qualidade de vida de pessoas com esclerose múltipla. BIOMOTRIZRevista Científica da Universidade de Cruz Alta. 2014;8(1).

62. Renger R. A review of the profile of mood states (POMS) in the prediction of athletic success. Journal of Applied Sport Psychology. 1993;5:78-84.

63. Vanden Auweele Y, De Cuyper A, Van Mele V, Rzewnicki R. Elite performance and personality: from description and prediction to diagnosis and intervention. status: published. 1993.

64. Prapavessis H. The POMS and sports performance: A review. Journal of Applied Sport Psychology. 2000;12:34-48. 